\title{
Berlinale 2000 Report
}

\author{
By Ron Holloway
}

Spring 2000 Issue of KINEMA

\section{BERLINALE 2000 AT FIFTY}

FOR the first time in the history of the festival, the 50th Berlinale (9-20 February 2000) was opened by the President of the Federal Republic of Germany, Johannes Rau. German Chancellor Gerhard Schroeder joined Berlin Mayor Eberhard Diepgen at the grand inauguration of the new festival location cum headquarters on the Potsdamer Platz. Cultural Minister Michael Naumann presented Jeanne Moreau with an honorary Golden Bear and chatted with her about co-founding a new German-French Film Academy. L'Oréal sponsored the VIP lounge. The party for Danny "Trainspotting" Boyle's screen adaptation of Alex Garland's The Beach (UK-USA), starring Leonardo DiCaprio, was voted the festival's most lavish and exotic. Kenneth Branagh enlivened the press conference for his Love Labour's Lost (UK) with a droll quote: "Shakespeare has been an excellent meal ticket!" MPAA's Marc Spiegel reminisced how the Berlinale became a major international festival event a half-century ago. Wolfgang Jacobsen's splendid anniversary publication, 50 Years Berlinale -- Internationale Filmfestspiele Berlin is packed with nostalgic memorabilia for those who still miss the Zoo Palast, a proud flagship venue on the festival circuit. And Between Barricades and Ivory Tower, The History of Independent Cinema: 30 Years International Forum of Young Cinema, edited by Nicolaus Schröder for the "Friends of the German Kinemathek," also belongs on the shelf of every dedicated cinéaste.

As for the innovations at the anniversary Berlinale, the Stella Musical Theatre on Marlene-Dietrich-Platz was re-christened the "Berlinale Palast" for the duration of the festival. Despite the faulty sightlines that made reading subtitles a neck-wrenching ordeal, its seating capacity of 1600 is a whopping $50 \%$ increase over the 1000 at the Zoo Palast. The additional venues in the neighbouring Cinemaxx and CineStar on the Potsdamer Platz, each multiplex with venues seating up to 600, offered optimal facilities for sidebar and market screenings. The site for the European Film Market in the Debis building lacked only a come-together meeting-point and dining facility, an oversight that Berlinale director Moritz de Hadeln said he would correct next year. The International Forum of Young Cinema under co-director Ulrich Gregor moved into its new offices in the Sony Center, where the Deutsche Kinemathek Berlin and the Film Museum Berlin will also be permanently housed after another grand opening this June. All things considered, these innovations, with more to come in the future, boosted the image of a new Berlinale in a new capital in a new century in a new millennium.

Of the half-dozen avant-premiere Hollywood productions booked by the Berlinale just prior to, or on the day of, their official German release, three were nominated for Oscars: Magnolia (Best Original Screenplay and Best Supporting Actor: Tom Cruise), The Hurricane (Best Actor: Denzel Washington) and The Talented Mr. Ripley (Best Supporting Actor: Jude Law). Of these, Norman Jewison's The Hurricane made the biggest impact with the audience: a standing ovation for Denzel Washington at the festival premiere for both the emotional and physical stamina required to interpret boxer Rubin "Hurricane" Carter, who had been imprisoned for 19 years on the charge of murder until his case was reopened and he was acquitted. Of course, The Hurricane has its cinematic forerunner -- in Norman Jewison's own In the Heat of the Night (1967), starring Sidney Poitier as a black detective who is stalked by rednecks in a southern town for investigating a murder. And the Canadian director added: "Back in 1943, when I was 17, I hitch-hiked through the Deep South and encountered segregation and apartheid first-hand. That kind of experience sticks with you."

\section{Accolades on Marlene-Dietrich-Platz}

One of the most exciting events at the 50th Berlinale was the presence of Andrzej Wajda. A frequent guest in the past at the festival, the veteran Polish master served this year as member of the international jury. His new film, Pan Tadeusz, based on Adam Mickiewicz's epic poem, was given a special screening in the main programme -- meanwhile, back in Poland, it was breaking box office records (at last count an audience of over 7 million). Add to this the news that, on March 26, he would be presented with an Honorary Academy Award in Los Angeles. Further, the Andrzej Wajda -- Philip Morris Freedom Prize, founded a year ago in Berlin by the American Cinema Foundation and named in his honour, was awarded for the first time to Kira 
Muratova. The talented Ukrainian director, whose Asthenic Syndrome won a Silver Bear at 1990 Berlinale, presented her latest short film, Letter to America, in the Panorama. And the award ceremony, a dignified affair at City Hall attended by VIPs and film professionals, was enriched even more when the Ukrainian Ministry of Culture announced that Muratova's next film will receive its full support.

When Andrzej Wajda was asked why he would want to film Pan Tadeusz in the first place, a monumental 12-canto, 13-syllable-metre epic poem, he answered bluntly: "Pan Tadeusz is a film that speaks to the soul of every Pole -- any school child can recite from memory some lines from Adam Mickiewicz's romantic hymn to the human spirit penned in exile from Paris in 1834." His big-budget film -- running at 150 minutes at home, 120 minutes abroad -- scores as an epic in its own right: idyllic rural landscapes, Lithuanian gentry and village life, Napoleon's campaign against Russia, a family feud with the tender, sensitive, delicate Zofia as the pawn, Polish romanticism in the hands of Poland's legendary romantic director. Add to this some remarkable performances by national stage-and-screen personalities -- Boguslaw Linda, Daniel Olbrychski, Grazyna Szapolowska, Andrzej Seweryn, Marek Kondrat, joined by attractive newcomer Alicja BachledaCirus as Zofia -- in addition to top professionals in the production credits, and you have the phenomenal rebirth of Polish cinema. Although a lofty aesthetic challenge to the average viewer at the Berlinale, Pan Tadeusz was worth every minute of the viewing experience.

For the second year in a row, the Golden Bear was awarded to an American entry. Paul Thomas Anderson's three-hour Magnolia confirms the 29-year-old writer-director -- whose first feature Hard Eight (1996) was developed at the Sundance Workshop, and whose second feature Boogie Nights (1997) stripped the mask away from the LA porno industry -- as one of the bright talents on the independent scene today. Seven separate stories, each flushed with tragic moments and comic twists, are linked together by way of coincidental events and overlapping family relationships into a seamless pattern of "what could have happened" over a 24-hour stretch. The metaphorical setting, Magnolia Boulevard, runs through San Fernando Valley, the same general area that provided locations for Hard Eight and Boogie Nights.

On the funny side, we meet a do-good cop on his rounds of disturbances, a goofy ex-quiz-kid champion who can neither hold a job nor sustain an intelligent conversation, and a marketing macho conducting a "seduce-and-destroy" seminar for frustrated males. On the ledger of human failings, we are confronted with a father who has abused his daughter, a money-grabbing parent who exploits his ingenious son, and a dying TV producer who wants to make up with a long-lost son for the sins of the past. Add to these one striking image of surreal brilliance -- an apocalyptic shower of frogs! -- and it's difficult to walk away from this tragicomedy without feeling some pangs of remorse for one or other of the feeble, vulnerable losers.

Just as Anderson exposes the soft underbelly of the TV quiz-show, Miloš Forman takes a sledge-hammer to the canned-laughter sitcom in Man on the Moon, starring Jim Carrey as the schizophrenic performance artist Andy Kaufman, whose loony antics and bizarre gags disturbed the industry as much as enriched it. Kaufman's early death at 35 of cancer adds to the legend, while Carrey's hilarious yet sensitively honest interpretation of a standup comedian who swore by the unpredictable ("I don't even know what's funny!") might well make him a familiar name to European audiences. Miloš Forman received a Silver Bear for Best Director.

Oliver Stone's Any Given Sunday, also kicks the shins of an American institution: the multi-million-dollar business of professional football. True, its visual appeal is geared to the game's head-on collisions, fast-action sprints, and soaring quarterback throws. But there is enough vintage Stone morality to muse over at halftime: the quasi-religious aspects of a dangerous gladiator sport with its latent racism, backroom political maneuvers, money-grabbing shenanigans, life-damaging injections, crooked sportcasters, and manipulative advertising spots. "Football is basically a metaphor for life," said Stone in an interview. "The film goes to the heart of American: it's about insecurity, volatility, and change." Although Any Given Sunday runs out of gas long before the final whistle is blown, a deft performance by Al Pacino as the aging coach and a cameo by Stone himself as the wise-guy TV commentator hint that the director, maybe, has changed his style from the harsh pessimistic tones of Nixon and Natural Born Killers to a more upbeat and positive estimate of the human condition.

Three German entries by veteran directors enlivened the competition -- and all were awarded by the international jury. Wim Wenders's The Million Dollar Hotel, an American co-production shot in English and 
filmed in Los Angeles, received the Jury Prize (Silver Bear). Set in the year 2001 in a rundown hotel that has seen better days, the place is peopled by bums, misfits, oddballs, deviates, junkies, would-be artists, and other aberrations of the American Dream. When the gentle, berserk, accommodating Tom Tom (Jeremy Davies) commits suicide by leaping from the roof, his story is then told in flashback -- and we meet the weirdest character of all: the spaced-out FBI Agent Skinner (Mel Gibson). Skinner has been enlisted by a billionaire media mogul to investigate the death of his son, last seen in the company of Tom Tom and the prostitute Eloise (Mila Jovovich). That's about it, save for a wasted cameo by Gloria Stuart, memorable as the engaging starlet in John Ford's Airmail (1932) and the effervescent storyteller in James Cameron's Titanic (1997). Entranced by the medium, Wenders has a tendency to let actors drift for themselves.

Bibiana Beglau and Nadja Uhl shared the Silver Bear for Best Actress for their roles in Volker Schlöndorff Die Stille nach dem Schuss (Rita's Legends). A controversial film before it even hit the screen, it tells the story of Rita Vogt, a West German RAF (Red Army Faction) terrorist who goes underground in East Germany to live under new identities -- the "legends" given her by the Stasi (State Security Police) -- until the fall of the wall and her arrest by the West German authorities. Its festival appearance immediately provoked a protest from ex-terrorist Inge Viett, who claimed that the film drew upon her published autobiography.

Whether or not Schlöndorff and screenwriter Wolfgang Kohlhaase borrowed significantly from Viett's reallife chronicle to make Rita's Legends may have to be resolved before the German release (planned for next September), but as it stands this is a rather conventional film: part melodrama, part psychological thriller, part fiction-documentary. It does, however, depict quite accurately just how sterile, how regulated, how petit-bourgeois life in the socialist East was during the 1980s all the way up to the fall of the wall. Rita's Legends also received the Blue Angel Award for Best European Film.

Awarded a Silver Bear for the "ensemble's outstanding artistic achievement," Rudolf Thome's Paradiso -Sieben Tage mit sieben Frauen (Paradiso -- Seven Days with Seven Women) was the surprise of the festival.

A glance back at his oeuvre reveals an auteur who seldom deviates from an easy-going, tongue-in-check narrative style, one that links specific actors to variations on the same theme: personal discourse on the fragile bonds that form a relationship. Paradiso, a modern parable with biblical/mythical connotations, takes up where an earlier trilogy -- Der Mikroskop (The Microscope, 1986), Der Philosoph (The Philosopher, 1988), and Seven Women, 1989) -- left off.

In Paradiso Adam (Hanns Zischler), a symphonic composer, lives with Eva (Cora Frost), his young wife and mother of his children, in the placid lake country north of Berlin, a natural paradise aptly suited to his creative temperament. When Eva hits on the idea of celebrating Adam's 60th birthday together with the seven loves of his past life, the composer readily agrees. And so this "divine comedy" of seven days spent with seven women unfolds as a kind of revelation of past regrets, coupled however with a meditation on the present and the future. Since Rudolf Thome himself has also just turned sixty, and since Hanns Zischler has served as the director's alter ego before -- the architect in Berlin Chamissoplatz (1980) -- Paradiso can be taken as a personal reflection on the passage of time at the prime of life and the dawn of a new century -"comic, ironic, quite simple" (Thome).

According to François Ozon, his screen adaptation of Gouttes d'eau sur pierres brûlantes (Water Drops on Burning Rocks), a French-Japanese co-production, dates from an unpublished play by 19-year-old Rainer Werner Fassbinder titled Tropfen auf heisse Steine that was found in his legacy as a typed manuscript. According to film historian Hans Helmut Prinzler, however, the play was begun in 1965 when Fassbinder was 20 and completed a year later. To make matters more confusing, Ozon has transferred the dramatic reference a half-decade later to the 1970s, using Fassbinder's The Bitter Tears of Petra von Kant (1972) as a model. All of which underscores the hazard that Water Drops on Burning Rocks is more an "inspiration" than a "discovery," and one with seminal RWF references: latent homosexuality, impossibility of love, couples in an intertwined relationship. As for the film itself, François Ozon has directed a low-budget kammerspiel in which young, naive Franz (Rainer's alter ego) moves in with older Leopold (played by the popular French actor Bernard Giradeau), only to have the relationship marred when former girlfriends of the pair appear on the scene (one of whom is Anna Thompson, the American independent cult idol).

Two women directors deftly interpreted dreams and nightmares. In Laetitia Masson's Love Me (France), 
Gabrielle (Sandrine Kiberlain) encounters herself as a young girl and meets her long lost mother in this complex journey into memories and daydreams. Her trip takes her to Memphis (read "Love Me Tender" into the title), where she eludes the grasp of a mysterious guardian, meets French rock star idol Johnny Hallyday (of "Heartbreak Hotel" fame), spends the night with him, and finally musters the courage to free herself of a couple ghosts from the past. This is the last film in her trilogy on love and longing, following En avoir (ou pas) (To Have or Have Not, 1995) and A vendre (For Sale, 1998). By contrast, in Mary Harron's American Psycho (USA), based on Bret Easton Ellis's cult shock-novel of the 1980s, a Wall Street investment broker (Christian Bale), high on cocaine and body lotions, fabricates a nightmare of outrageous blood-bath murders. A modern-day Jack the Ripper? Hardly, says Mary Harron. "I found the book very funny, a brilliant satire." Her debut feature, I Shot Andy Warhol (1996), adroitly wrested humour from the macabre, and American Psycho runs in the same vein.

Besides Laetitia Masson in the competition, two other French women directors also made their mark in the International Forum of Young Cinema. Claire Denis's Beau travail (Good Work), presented previously at Venice in the competition, drew upon American writer Herman Melville's "Billy Budd" (found among his papers in 1924) to fulfill an assignment at La Sept/ARTE on the theme "Foreign Countries" -- that is, stories about French people living abroad. Since Denis had been raised in Africa, she returned to the Gulf of Djibouti, where the French Foreign Legion maintains a training base, to explore the moral question of good and evil, love and hate, in a closed community as recorded in the diary of a jealous non-commissioned officer (Denis Lavant). Filmed almost without dialogue, Good Work fascinates as a chain of episodes minimalist in concept and realization, as a choreography of gleaming, sun-baked bodies moving in rhythm against a backdrop of sea, sand, and desert. Claire Devers's La voleuse de Saint Lubin (The Thief of Saint Lubin), too, comes across as a chain of events -- strokes of fate, if you will -- all tied neatly together in the format of a docu-drama to expound on the injustice of the justice system. Drawing upon a true incident as reported in French newspapers, this is the story of a young mother who was acquitted in family court of stealing groceries in supermarkets to feed her children, only to be convicted by an appeal court because one of supermarket managers felt he had to press charges to set an example. Dominique Blanc gives a highly charged emotional performance as the victimized heroine.

Save for the aforementioned Pan Tadeusz, the only other important entry from an Eastern European filmland was Alexander Proshkin's costly Russkiy Bunt (Russian Revolt, Russia-France). The story of the peasant uprising under Pugachev as rendered in Alexander Pushkin's novel "The Captain's Daughter" (published 1836, the year before the poet's death in a duel), the same source had already been adapted by Dino De Laurentiis for La Tempesta (The Tempest, 1958), an extravagant Italian-French-Yugoslav co-production directed by Alberto Lattuada and starring American actor Van Heflin as Pugachev. Still, the very fact that Alexander Proshkin -- best known for his perestroika film, The Cold Summer of 1953 (1988) -- could assemble such a large cast of professionals to make this quite impressive epic says something for the recovery of Russian cinema. In fact, Russia may be one of the few places left for historical productions on such a monumental scale.

By contrast, Ljubisa Samardzic's Nebeska udica (Sky Hook, Yugoslavia-Italy) confirmed that Yugoslav cinema is not only alive and well, but also that Serb directors have been accomplishing minor miracles over the past decade with their string of socially engaged, politically conscious, low-budget productions. Shot in the ruins of a bombed-out section of Belgrade, Sky Hook speaks simply and directly to the human spirit and the will to endure, using the metaphor of a makeshift basketball court as a moral response to the presence mafia, the evils of the black-market, the corruption in the government, the broken marriages, and the decision of the weary to leave the country for the good of their children. Produced by an actor now making his debut as director, the 63-year-old Samardzic well deserved an invitation to the competition, for few have fought as hard to keep Yugoslav cinema afloat despite the odds.

Another Balkan film just as impressive for its sociopolitical content was the Croatian entry in the International Forum of Young Cinema: Vinko Bresan's Marsal (Marshal Tito's Spirit), awarded the prestigious Wolfgang Staudte Prize by an independent jury. A black comedy along the same lines as his earlier How the War Started on My Island, 1996), Grand Prize winner at the 1997 Cottbus Festival of Young East European Cinema, Marshal explores the possibility of the return of Tito, or Tito's ghost, to a small island community in the Adriatic Sea, where "Veterans of the WW2 Liberation Army" are still keeping watch as guardians of 
partisan honour. The ghost turns out to be a senile escapee from an insane asylum, someone who has put on a uniform and proclaimed he's Tito -- but no matter: that's enough to rouse the vigilante veterans to take over the island and install a military court to punish the greedy capitalists of the new order. As funny as this parody is, the fantasy of such an oddball uprising is not that far from reality, considering low pensions for old veterans and the demise of a once-proud Yugoslavia under a legendary partisan hero.

\section{Asian Cinema}

Asian cinema has become the indispensable lifeline of the festival. Over 30 films from the Near and Far East, the Subcontinent and Central Asia, were screened at the Berlinale: 6 in the Official Program, 18 (plus 6 on video) in the Forum, 7 in the Panorama, 3 in the Children's Film Festival, in addition to a handful of co-productions with Western countries. Of these, a round dozen were Japanese productions, two of which received top festival awards.

Akira Ogata's Dokuritsu shonen gasshoudan (Boy's Choir), awarded (by some oddity) the Alfred Bauer Prize for Best Debut Film, introduces a 40-year-old director who had previously made several tele-features, docudramas, and pop-music-videos. Set in the politically volatile 1970s, the title refers to an imitation Viennese Boys Choir at a Catholic boarding school in the far north of Japan, where two distraught teenagers with soprano voices form a friendly alliance -- until they get caught up in the revolutionary songs and slogans of the day. A curious subject for a Japanese feature, Boy's Choir provokes as much as it teases. Just as curious and fascinating from a cultural point of view was Yuji Nakae's Nabbi no ko (Nabbie's Love), co-winner of the NETPAC Prize. Filmed on the island of Okinawa, far from Tokyo's cultural straightjacket, and enhanced by a soundtrack of typical Okinawan music, Nabbie's Love recounts an elderly woman's lost love down to a reunion of the couple sixty years later. Since the story of this scandalous affair is seen through the eyes of the granddaughter, the generation gap adds yet another perspective to the already evident spiritual affront to mores and manners.

The special screening of Kon Ichikawa's Dora-Heita was an event onto itself -- indeed, the one moving moment of the festival. Not only is this the Japanese director's 74th film, but the screenplay was penned thirty years ago together with Akira Kurosawa, Keisuke Kinoshita, and Masaki Kobayashi to help launch their independent Yonki-no-Kai (roughly: "Four Musketeers") production company. But when Kurosawa's Dodes' ka-den (1970), a rambling account of life in a Tokyo shanty-town, flopped at the box office, the company folded and the script was shelved -- until Ichikawa picked it up again to pay tribute to deceased friends and bygone days. As old-fashioned as this Samurai story appears at first glance -- a magistrate (nicknamed "Dora-Heita") is sent to clean up a corrupt fief -- in Ichikawa's deft hands it combines humour with sword-play to tell a diverting story. Koji Yakusho, an exceptional actor memorable for his performance as the paroled murderer in Shohei Imamura's Unagi (The Eel), the Golden Palm winner at the 1997 Cannes festival, poses this time as a dissolute government employee given to gambling, carousing, and the company of geishas in order to infiltrate the inner-circle of the yakuza clan.

The international jury, with Gong Li as president, voted Zhang Yimou's Wo de fu qin mu qin (The Road Home, China) the Grand Jury Prize, the runner-up Silver Bear. Back at the 1988 Berlinale, she was featured in Zhang Yimou's Hong gaoliang (Red Sorghum), the Golden Bear winner, and both went on from there to become bright names in the Chinese film revival. The Road Home, despite the sentimentality of this 1950s tale about a woman's undying love for her school-teacher husband in a village of northern China, does bear the stylistic signature of a director with an accurate eye for images that count -- as when the dull, drab colours of the wintery present give way to the colourful, rapturous hues of an autumnal past. Zhang also has a sure hand for handling actors, the factor missing in Sun Zhou's Piao liang ma ma (Breaking the Silence), the Chinese film given a special screening. Another sentimental heartbreaker, it features Gong Li in the emotional role of a loving mother dealing with the dilemma of a deaf child.

Two Asian films about filmmaking were standouts. Calcutta director Rituparno Ghosh, co-winner of the NETPAC Prize for Bariwali (The Lady of the House), returned to the Forum after the success of his Dayan (Crossfire) here two years ago. The story of a lonely spinster whose mansion is rented out to a film team for three weeks of shooting, only to have the sensitivities of the naive woman manipulated for his own interests by the director, The Lady of the House recalls the best psychological portraits of Satyajit Ray and bears a remarkable resemblance to William Faulkner's classic short story "A Rose for Emily." Actress-celebrity Kiron 
Kher gives a fine performance as the middle-aged, exploited victim of an artist's subtle, creative instinct to achieve the best results at whatever costs to another human being.

By coincidence, Turkish director Nuri Bilge Ceylan also returned to the Berlinale after winning the Caligari Prize in 1998 for his Forum entry, Kasaba (The Small Town), the impressionistic portrait of family life in an isolated village. Invited to participate this year in the competition with Mayis Sikintisi (Clouds of May), Ceylan probes the psyche of a documentary filmmaker whose project in the Anatolian village of his birth prevents him from appreciating the obscure concerns of his father to claim a piece of land on which he has already built a house. Although the film in theme and style bears a slight resemblance to Abbas Kiarostami's Through the Olive Trees (Iran, 1994), yet another film-within-a-film exploration of the human condition, Nuri Bilge Ceylan is beyond question a filmmaker with his own signature. Indeed, how often do you find an auteur who handles every phase of production (producer, screenwriter, director, cameraman, set designer, co-editor) and leaves us with images drawn from a wooded landscape, the languid beauty of a summer evening, and the faces of people with deep roots in the rhythms and traditions of a rural community? Overlooked for award recognition, Clouds of May was my personal choice for the International Critics (FIPRESCI) Prize. Instead, it was awarded to Claude Miller's La chambre des magiciennes (Of Women and Magic, France), a tele-feature set in a neurological clinic that sidesteps the human drama before the camera to probe the visual possibilities of new DV (digital video) camera technology.

Finally, a surprise from Central Asia in the Panorama section. "When I was awarded both the Grand Prix and the Prize of the Russian Critics at the Kino Shok festival in Russia, I knew that my film had not only artistic merits, but also something important to say about the changes in our society," said Yusuf Razykov about Voiz (Orator), the first feature film from Uzbekistan ever presented at the Berlinale. An historical panorama set against the background of the Russian Revolution, one that portrays the straight-jacket conformism of communist ideology, Orator could not have been made ten years ago. But what makes it a standout among productions in Central Asia is its forthright treatment of the Moslem religion, its subtle touches of comedy mingled with tragedy, and its decision to dispense with propaganda of any sort. Inflashback, the film's narrator recalls the dilemma of his grandfather: Iskander, a simple man and cart-carrier, had three wives (two placed in his care upon the death of his brother, as was the custom), became a likeable leader in the community, and found himself thrust unwillingly into the maelstrom of the revolution by forces beyond his control. While Iskander is striving to resolve these conflicts, the communists begin to eat their own revolutionary leaders.

\section{Documentary Highlights}

German documentaries received top billing at the 30th International Forum of Young Cinema. Indeed, a Forum presentation of the latest chapter in Barbara and Winfried Junge's ongoing chronicle, Die Kinder von Golzow (The Children of Golzow) has been pretty much expected over the past two decades. A glance at the record shows that, back in 1982, Ulrich and Erika Gregor invited the Junges' collective portrait, Lebensläufe -- Die Geschichte der Kinder von Golzow in einzelnen Porträts (Paths of Life -- The Story of the Children of Golzow in Individual Portraits) to the Forum for the first time, followed a decade later by a permanent festival commitment. Drehbuch: Die Zeiten -- Drei Jahrzehnte mit den Kinder von Golzow und der DEFA (Screenplay: The Times -- Three Decades with the Children of Golzow and the DEFA) was programmed in 1993, Das Leben von Jürgen von Golzow (Jürgen of Golzow: His Life) in 1994, Die Geschichte vom Onkel Willy aus Golzow (The Story of Uncle Willy from Golzow) in 1995, Da habt Ihr mein Leben, Marieluise -Kind von Golzow (I'll Show You My Life, Marieluise -- A Child of Golzow) in 1997, and Brigitte und Marcel -- Golzower Lebenswege (Brigitte and Marcel -- Lifelines from Golzow) in 1999.

Now, for the seventh time, we return at the Forum to meet another member of that first-grade class of 1961 in Golzow, a village in eastern Germany (formerly the German Democratic Republic) near the Polish border. In Ein Mensch wie Dieter (Someone Like Dieter), the 16th documentary in the series, we trace an historical development that dates back to the construction of the Berlin wall and embraces near four decades of East/West German history. To be sure, the Junges and their team have provided us with a picture-book history of life and times in the former GDR, of the Wende (1989/90) period that witnessed the fall of the wall and subsequently the unification of Germany, and finally the efforts of those first-grade classmates to come to grips as grown adults with the demands of a new society. 
Who is Dieter Finger? For those acquainted with the previous chronicles, he was, and is, that chipper, easygoing, friendly day-dreamer who quickly became one of the favourites of the film team due to his outgoing personality and willingness to be filmed under any circumstances whatsoever. We see Dieter leaving school early to pursue a profession as carpenter, later sent with government permission to construction sites in Libya and West Germany, and finally as a master of his own destiny when, after the Wende, he manages to build a house with his own hands in the community in which he grew up. As with all of the individual portraits in the Golzow series, Someone Like Dieter is a documentary to be seen and treasured for its historical authenticity, its narrative simplicity, and its warm embrace of the human condition.

Other Forum documentaries were just as memorable. In Thomas Heise's Neustadt (STAU -- Stand der Dinge) -- Neustadt (STAU -- State of Affairs) the director revisits the same group of young rightist-radicals in Halle-Neustadt who had previously expounded their radical viewpoints in a 1992 documentary: STAU -- Jetzt geht's los (STAU -- Now It Begins). This time, Heise augments his social study with background information about a $13 \%$ election triumph of the rightist DVU political party. Eduard Schreiber's Zone M, a reflective documentary about everyday life in a Russian village nestled in the Ural mountains, takes an unexpected turn when UFOs are reported by the population. The director leaves no doubt that, following the downfall of communism, isolated communities like these are now left entirely on their own to search for security, happiness, and the meaning of life. Further, by needling the viewer with partial glimpses of a building in ruins -- gradually we realize that this was once a church -- Schreiber pinpoints one of the reasons for the community's spiritual malaise. And in the video section of the Forum you could experience a chilling moment of historical documentation: Romuald Karmakar's Das Himmler-Projekt (The Himmler Project). Karmakar has actor Manfred Zapatka deliver Heinrich Himmler's notorious three-and-a-half-hour speech on 4 October 1943 to a select group of 92 SS-Generals at a Leadership Conference in Posen -- an experience as unnerving as it is revealing.

Another Forum highlight was Gordian Maugg's Hans Warns -- Mein 20. Jahrhundert (Hans Warns -- My 20th Century), a fiction-documentary that reconstructs a real-life adventure. This is the story of a Hamburg youth's voyage on a freighter to Chile just before the outbreak of the First World War, only to find himself stranded there for the duration of the war. Maugg's deft skill in using old still-photographs, taken by the 14-year-old Warns with his tiny box-camera to record the adventures of his journey, to fabricate a grainy, scratchy, amateur-like silent film flushed with all the filmmaking techniques common to the early silent period with an appropriate musical soundtrack. All in all, this first portion of the Hans Warns odyssey makes for a magical experience -- indeed, one of the finest to be experienced in contemporary German cinema. Thereafter, we follow Warns as he matures to manhood, yet remains true to his chosen profession as a captain of freighters and merchant ships. His later voyages, interpreted by actors, take us to Egypt, Spain, Norway, and the trauma of My 20th Century -- the Second World War.

Finally, there was Pepe Danquart's Heimspiel (Home Game), the documentary hit of the Panorama. A sellout for all its performances, the big moment arrived when this hymn to ice-hockey played the spacious Zoo Palast -- and literally turned the place to an arena. On the surface, this high-gear, hitech-camera, close-up view of a fast-action sport rides the wave of rabid fans rooting for the "Eisbären" (Polar Bears), one of two German clubs based in Berlin. But as soon as Danquart delves into the past history of the club -- once it's known that the club used to be called "Dynamo" and was the pride of the financially strapped GDR -- we are confronted with an entirely different picture. Danquart recounts the club's exploits on the ice, its achievements against overwhelming economic odds, and the enthusiasm of the fans that spills over into the Berlin-Hohenschönhausen community. And after a while it becomes evident that he is taking the pulse of history -- in short, Home Game come across as a comprehensive, understanding, sympathetic portrait of East Berliners and Eastern German society after the fall of the wall. Who cares if the Eisbären club today is composed of Canadians and Swedes and Czechs and who knows what other nationality. For the fans, particularly those in the cheering-section, what counts the most is that all-important cross-town game with the Capitals in West Berlin, when "D-Y-N-A-M-O" can again be shouted to the rafters!

Compare Pepe Danquart's Home Game on ice-hockey with Oliver Stone's Any Given Sunday on American football, and the question is valid: are sport films today's metaphors for life? 


\section{References}

\section{AWARDS}

INTERNATIONAL JURY

Golden Bear

Magnolia (USA), Paul Thomas Anderson

Silver Bear, Grand Jury Prize

Wo de fu qin mu qin (The Road Home, China), Zhang Yimou

Silver Bear, Best Actress

Bibiana Beglau and Nadja Uhl, Die Stille nach dem Schuss (Rita's Legends, Germany), Volker Schloendorff

Silver Bear, Best Actor

Denzel Washington, The Hurricane (USA), Norman Jewison

Silver Bear, Best Director

Miloš Forman, Man on the Moon (USA)

Silver Bear, Jury Prize

The Million Dollar Hotel (Germany-USA), Wim Wenders

Silver Bear, Outstanding Artistic Achievement

Entire Cast in Paradiso -- Sieben Tage mit sieben Frauen (Paradiso -- Seven Days with Seven Women, Germany), Rudolf Thome

Golden Bear, Short Film

Hommage à Alfred Lepetit (Homage to Alfred Lepetit, France), Jean Rousselot

Silver Bear, Short Film

Media (Czech Republic), Pavel Koutsky

Blue Angel (AGICOA Copyright) Prize for Best European Film

Die Stille nach dem Schuss (Rita's Legends, Germany), Volker Schloendorff

Alfred Bauer Prize for Debut Film

Dokuritsu shonen gasshoudan (Japan), Akira Ogata

\section{OTHER AWARDS}

FIPRESCI (International Critics) Prizes

Competition: La chambre des magiciennes (Of Women and Magic, France), Claude Miller

Forum: Monday (Japan), Sabu

Panorama: Paragraph 175 (USA), Rob Epstein, Jeffrey Friedman

\section{Ecumenical Jury Prizes}

Competition: Wo de fu qin mu qin (The Road Home, China), Zhang Yimou Special Prize, Short Film: Media (Czech Republic), Pavel Koutsky

Panorama: Botin de guerra (Spoils of War, Argentina-Spain), David Blaustein

Special Prize, Short Film: Echo (Belgium), Frédéric Roullier-Gall

Forum: De grote vakantie (The Long Holiday, Netherlands), Jan van der Keuken

Special Prize: Cinéma Vérité: Defining the Moment (Canada), Peter Wintonick

Peace Film Prize

Long Day's Journey into Day -- South Africa's Search for Truth and Reconciliation (USA), Deborah Hoffmann, Frances Reid

Wolfgang Staudte Prize -- Forum

Marsal (Marshal Tito's Spirit, Croatia), Vinco Bresan 
Don Quixote Prize (International Federation of Film Societies)

Forum: I earini synaxis ton agrofylakon (The Spring Gathering, Greece), Dimos Avdeliodis

CICAE Prize (International Confederation of Art Cinemas)

Panorama: Saltwater (Ireland), Conor McPherson

Forum: I earini synaxis ton agrofylakon (The Spring Gathering, Greece), Dimos Avdeliodis

Guild of German Art House Cinemas Prize

The Hurricane (USA), Norman Jewison

Caligari Prize (German Association of Communal Film Work)

I earini synaxis ton agrofylakon (The Spring Gathering, Greece), Dimos Avdeliodis

NETPAC Prize -- Network for Promotion of Asian Cinema -- Forum

Bariwali (The Lady of the House, India), Rituparno Ghosh

Nabbie no koi (Nabbie's Love, Japan), Yuji Nakae

International Jury, Children's Film Festival

(ex aequo) Man van staal (Man of Steel, Belgium), Vincent Bal

Tsatsiki, Morsan och Polisen (Tsatsiki, Mum and the Policeman) (Sweden-Norway-Denmark), Ella Lemhagen

Crystal Bear, Young People's Jury, Children's Film Festival

Tsatsiki, Morsan och Polisen (Tsatsiki, Mum and the Policeman) (Sweden-Norway-Denmark), Ella Lemhagen

\section{Author Information}

Ron HOLLOWAY (1933-2009) was an American critic, film historian, filmmaker and correspondent who adopted Europe as his home in the early fifties and spent much of his life in Berlin. He was an expert on the study of German cinema and against all odds produced, with his wife Dorothea, the journal German Film, keeping us up-to-date with the work of directors, producers and writers and the showing of German films around the world.

In 2007, Ron Holloway and his wife were awarded the Berlinale Camera Award. Ron also received the Bundesverdienstkreuz (German Cross of Merit), Polish Rings, Cannes Gold Medaille, the American Cinema Foundation Award, the Diploma for Support of Russian Cinema and an honorary award from the German Film Critics' Association.

Ron was also a valued contributor to Kinema for the past fifteen years. 